\title{
Is There a Link Between PTSD and Autistic Disorders - A Description Based on Steroid Hormones
}

\author{
Med Benedikt Gasser* \\ Faculty of Medicine, University of Bern, Switzerland, Europe
}

Submission: October 21, 2018; Published: October 29, 2018

*Corresponding author: Med Benedikt Gasser, Faculty of medicine, University of Bern, Mittelhusstrasse 43 CH-3000 Bern.

Abstract

Some hints exist that there might be a relationship between PTSD and Autism in the way that in both entities steroid hormone homeostasis plays a central role, with mainly an involvement of androgens in Autism and with glucocorticoids in PTSD. From an (neuro) anatomical point of view for both clinical entities Hypothalamus-Pituitary-Adrenal gland structures are crucial, whereby for Autism additionally sex organs especially testes with its ingoing steroid homeostasis has relevance.

\section{Introduction}

Autism is described as pervasive development disorder. In the DSM-5, Autistic Disorder, Asperger's Disorder and PDD-NOS are replaced by the diagnosis of Autism Spectrum Disorder [1]. Autism spectrum disorders are generally characterized as difficulties in communication and social interaction as well as special behavior such as retaining routines and insisting on sameness or special interests [1]. Interestingly, newer findings from Switzerland imply, that there is a link between socioeconomic factors and autism spectrum disorders [2]. Already in the first work by Hans Asperger [3] it was described that some children were from one child families and it was implied that the manner and kind of parents were predisposing factors for this disorder. However, also newest analyzes from Switzerland imply that very often children with a diagnosis of Autism have an immigrational or a foreign background yielding to a possible similarity with post-traumatic stress disorders (PTSD) [2]. It was shown for the area of Zürich (the biggest city in Switzerland) in a cohort of 147 children with a typical relationship of boys to girls that concerning communicational skills, interestingly in $53 \%$ more than one language was spoken at home affecting behavior in general and especially communicational skills (mean 1.6 languages) [2-4]. In this cohort the share of families with immigrational background was clearly increased and only in $13 \%$ of the families German (the local language) was mothers' language of the children, whereby these findings are in line with others $[2,5,6]$. However, situation differs from region to region in Switzerland and from a therapeutic point of view it was several times mentioned that schoolish setting is secondary, however more important are adequately educated caregivers [2,7-9].

\section{Evidence acquisition}

From different side a link between PTSD and autism was made [10]. Although some hints exist that no single abnormality characterizes all individuals with PTSD [11], often CRH-ACTHGlucocorticoid system is addressed. Hints exist that PTSD is mainly characterized by a dysregulation of homeostasis of Cortisol and his stimulating parameters such as CRH, ACTH with its associated (neuro)anatomical structures such as Hypothalamus, Pituitary-or adrenal gland and often additionally Hippocampus [12-15]. More general a glucocorticoid dysregulation also on receptor level was implied in PTSD and therefore especially an involvement of zona fasciculata in adrenal gland is indicated [15-21]. In autism an often described hyperandrogenemia is described, which is also in line with typical stated theories such as extreme male theory of autism [22-25]. Analyses in amnion fluid showed increased concentration of $\Delta 4$ sex steroids such as progesterone, $17 \alpha$-hydroxy-progesterone, androstenedione and testosterone [26]. An involvement of adrenal gland and additionally testes in boys and probably ovary in girls as location of steroid hormone synthesis is likely [22-25]. As a consequence, the control underlies the GnRH respectively FSH and LH regulation. Although, in its clinical presentation it is often difficult to distinguish on organ level probably different signal cascades are altered yielding to the differences in these two disorders.

\section{Discussion}

Some hints exist that there might be a relationship between PTSD and Autism. However, there are clear differences between these two entities in its etiopathogenetic development. Autism is 
a pervasive development disorder often beginning in early childhood and persisting over the whole life $[1,2,10]$. Nevertheless, besides some equalities in clinical presentation the underlying mechanism seem to differ yielding to differences in clinical presentation. Posttraumatic stress disorder is associated with hypothalamus-pituitary-adrenal (HPA) axis response to stressors, but links to neurophysiological and neuroanatomical changes are unclear [27].

Concerning autism it's allowed to presume that milder forms of autistic disorder evoke through decades of stimuli-reaction answer coupled with Hypothalamus-pituitary adrenal gland axis, probably in a similar way as in PTSD. As a way to an understanding HPA Axis respectively steroid hormones can be mentioned for ASD as well as PTSD. Increased stress yields to an increased activation of $\mathrm{CRH}$ on Hypothalamus level with stimulating effect on ACTH on pituitary level provoking an answer on adrenal gland level. To sum up, the involved steroid hormones in both entities differ and research focus is much more on androgens for autism whereas on glucocorticoid in PTSD indicating the relevance of steroid hormone homeostasis for both disorders.

\section{References}

1. American Psychiatric Association (2013) Diagnostic and Statistical Manual of Mental Disorders. ( $5^{\text {th }}$ edn) American Psychiatric Publishing, Arlington, VA, USA.

2. Schaefer C, Schneider N, Jenni O, Rhein Frühe, M (2018) Fördermassnahmen für Kinder mit Autismus-Spektrum-Störung - Die Situation im Kanton Zürich. Schweizerische Zeitschrift für Heilpädagogik, Jg.

3. Asperger H (1944) Die Autistischen Psychopathen im Kindesalter. Archiv für Psychiatrie und Nervenkrankheiten 117: 76-136.

4. Eckert A (2015) Autismus-Spektrum-Störungen in der Schweiz. Lebenssituation und fachliche Begleitung (HfH Reihe). Edn SZH/CSPS: Bern, Switzerland.

5. Keen D, Reid F, Arnone D (2010) Autism, ethnicity and maternal immigration. The British Journal of Psychiatry 196(4): 274-281

6. Welterlin D, Reid F, Arnone D (2010) Autism, ethnicity and maternal immigration. Br J Psychiatry 196(4): 274-281

7. Eckert A, Canonica C, Ullrich K, Markowetz R (2018) Evidenzbasierte schulische Förderung bei Autismus-Spektrum-Störungen. Schweizerische Zeitschrift für Heilpädagogik 24(9): 6-13.

8. Eckert A, Sempert W (2012) Kinder und Jugendliche mit Autismusspektrumstörungen in der Schule. Entwicklung eines Rahmenmodells der schulischen Förderung. Vierteljahresschrift für Heilpädagogik und ihre Nachbargebiete 3: 221-233.

9. Dittli D (2018) Lernende mit Autismus-Spektrum-Störungen: Strategie im Kanton Luzern. Schweizerische Zeitschrift für Heilpädagogik 9: 2025.

10. Kuhl-Meltzoff K, Stavropoulos, Bolourian Y, Blacher J (2018) Differential Diagnosis of Autism Spectrum Disorder and Post Traumatic Stress Disorder: Two Clinical Cases. J Clin Med 7(4): 71.

11. Rasmusson AM, Pineles SL (2018) Neurotransmitter, Peptide, and Steroid Hormone Abnormalities in PTSD: Biological Endophenotypes Relevant to Treatment. Curr Psychiatry Rep 20(7): 52.
12. Szeszko PR, Lehrner A, Yehuda R (2018) Glucocorticoids and Hippocampal Structure and Function in PTSD. Harv Rev Psychiatry 26(3): 142-157.

13. Algamal M, Ojo JO, Lungmus CP, Muza P, Cammarata C, et al. (2018) Chronic Hippocampal Abnormalities and Blunted HPA Axis in an Animal Model of Repeated Unpredictable Stress. Front Behav Neurosci 12: 150 .

14. Wichmann S, Kirschbaum C, Böhme C, Petrowski K (2017) Cortisol stress response in post-traumatic stress disorder, panic disorder, and major depressive disorder patients. Psychoneuroendocrinology. 83: 135-141.

15. Pooley AE, Benjamin RC, Sreedhar S, Eagle AL, Robison AJ, et al. (2018) Sex differences in the traumatic stress response: the role of adult gonadal hormones. Biol Sex Differ 9(1): 32.

16.Zenko MY, Baranova KA, Rybnikova EA (2018) Pathogenetic Role of the Stress-induced Release of Glucocorticoid Hormones in the Development of Post-traumatic Stress Disorder: An Experimental Study. Dokl Biol Sci 479(1): 51-53.

17. Watkeys OJ, Kremerskothen K, Quidé Y, Fullerton JM, Green MJ (2018) Glucocorticoid receptor gene (NR3C1) DNA methylation in association with trauma, psychopathology, transcript expression, or genotypic variation: A systematic review. Neurosci Biobehav Rev 95: 85-122.

18. Pan X, Wang Z, Wu X, Wen SW, Liu A (2018) Salivary cortisol in posttraumatic stress disorder: a systematic review and meta-analysis. BMC Psychiatry (1): 324.

19. Usta MB, Gumus YY, Say GN, Bozkurt A, Şahin B, et al. (2018) Basal blood DHEA-S/cortisol levels predicts EMDR treatment response in adolescents with PTSD. Nord J Psychiatry 72(3): 164-172.

20. van Zuiden M, Haverkort SQ, Tan Z, Daams J, Lok A, et al. (2017) DHEA and DHEA-S levels in posttraumatic stress disorder: A meta-analytic review. Psychoneuroendocrinology. 84: 76-82.

21. Walker SE, Sandi C (2018) Long-term programing of psychopathologylike behaviors in male rats by peripubertal stress depends on individual's glucocorticoid responsiveness to stress. Stress 7: 1-10.

22. El-Baz F, Hamza RT, Ayad MS, Mahmoud NH (2014) Hyperandrogenemia in male autistic children and adolescents: relation to disease severity. Int J Adolesc Med Health 26(1): 79-84

23. Ruta L, Ingudomnukul E, Taylor K, Chakrabarti B, Baron Cohen S (2011) Increased serum androstenedione in adults with autism spectrum conditions. Psychoneuroendocrinology. 36(8): 1154-1163.

24. Knickmeyer R, Baron Cohen S, Fane BA, Wheelwright S, Mathews GA, et al. (2006) Androgens and autistic traits: A study of individuals with congenital adrenal hyperplasia. Horm Behav. 50(1):148-153.

25. Majewska MR, Hill M, Urbanowicz E, Rok Bujko R, Bien'kowski P, et al. (2014) Marked elevation of adrenal steroids, especially androgens, in saliva of prepubertal autistic children. Eur Child Adolesc Psychiatry 23: 485-498.

26. Baron Cohen S, Auyeung B, Norgaard Pedersen B, Hougaard DM, Abdallah MW, et al. (2015) Elevated fetal steroidogenic activity in autism. Molecular Psychiatry 20(3): 369-376.

27. Cooper O, Bonert V, Moser F, Mirocha J, Melmed S (2017) Altered Pituitary Gland Structure and Function in Posttraumatic Stress Disorder. J Endocr Soc 1(6): 577-587. 
This work is licensed under Creative Commons Attribution 4.0 License

DOI: 10.19080/GJIDD.2018.05.555663
Your next submission with Juniper Publishers will reach you the below assets

- Quality Editorial service

- Swift Peer Review

- Reprints availability

- E-prints Service

- Manuscript Podcast for convenient understanding

- Global attainment for your research

- Manuscript accessibility in different formats

( Pdf, E-pub, Full Text, Audio)

- Unceasing customer service

Track the below URL for one-step submission

https://juniperpublishers.com/online-submission.php 